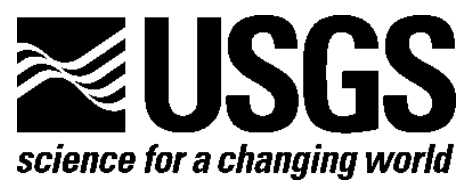

\title{
Synthesis of Tree Swallow (Tachycineta bicolor) Data for Beneficial Use Impairment (BUI) Assessment at Wisconsin Areas of Concern
}

By Christine M. Custer, Thomas W. Custer, and Paul M. Dummer

Open-File Report 2018-1032

U.S. Department of the Interior

U.S. Geological Survey 


\title{
U.S. Department of the Interior \\ RYAN K. ZINKE, Secretary
}

\section{U.S. Geological Survey \\ William H. Werkheiser, Deputy Director \\ exercising the authority of the Director}

\author{
For more information on the USGS-the Federal source for science about the Earth, \\ its natural and living resources, natural hazards, and the environment-visit \\ https://www.usgs.gov/ or call 1-888-ASK-USGS (1-888-275-8747). \\ For an overview of USGS information products, including maps, imagery, and publications, \\ visit https://store.usgs.gov/.
}

Any use of trade, firm, or product names is for descriptive purposes only and does not imply endorsement by the U.S. Government.

Although this information product, for the most part, is in the public domain, it also may contain copyrighted materials as noted in the text. Permission to reproduce copyrighted items must be secured from the copyright owner.

Suggested citation:

Custer, C. M., and Custer, T. W., 2018, Synthesis of tree swallow (Tachycineta bicolor) data for Beneficial Use Impairment (BUI) assessment at Wisconsin Areas of Concern: U.S. Geological Survey Open-File Report 2018-1032, 8 p., https://doi.org/10.3133/ofr20181032.

ISSN 2332-354X (online) 


\section{Acknowledgments}

We thank Laura E. Solem and Sean M. Strom for review of the manuscript, and all of the landowners who allowed us to place nest boxes on their properties. 


\section{Contents}

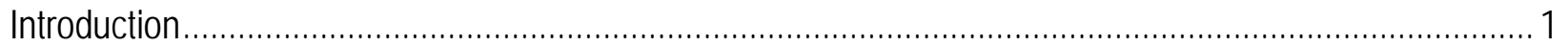

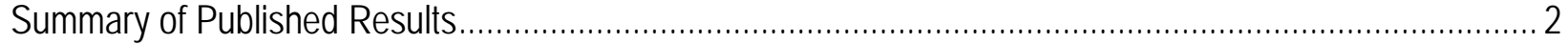

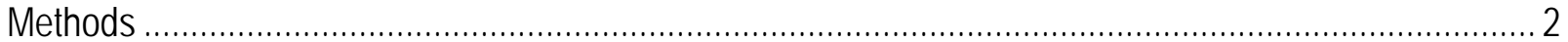

Exposure to Polychlorinated Biphenyls .................................................................................... 3

Exposure to Other Contaminants ............................................................................................ 3

Reproductive Success as a Beneficial Use Impairment Assessment Endpoint-Polychlorinated

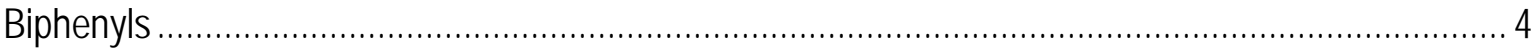

Reproductive Success and Other Contaminants........................................................................... 5

Biomarkers and Beneficial Use Impairment Assessment ................................................................... 5

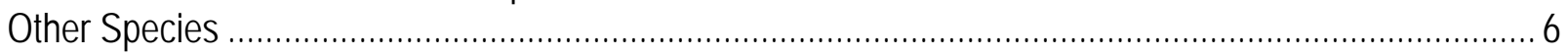

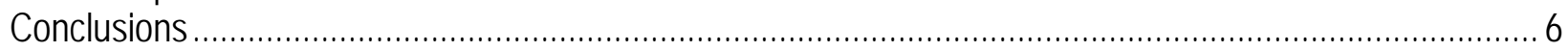

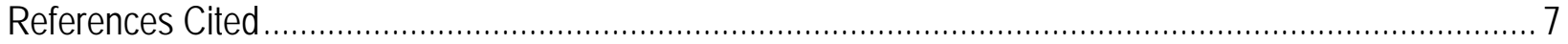

\section{Tables}

1. Tree swallow (Tachycineta bicolor) nesting sites investigated within the Wisconsin Areas of

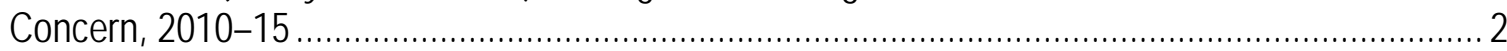

\section{Supplemental Information}

Concentrations of chemical constituents in tissues are given as either micrograms per gram $(\mu \mathrm{g} / \mathrm{g})$ or nanograms per gram $(\mathrm{ng} / \mathrm{g})$ wet weight.

All data presented are from Custer and others, 2016, 2017a, 2017b, and 2018 unless otherwise noted.

\section{Abbreviations}

$\begin{array}{ll}\text { AOC } & \text { Area of Concern } \\ \text { BUI } & \text { Beneficial Use Impairment } \\ \mathrm{Cl} & \text { confidence interval } \\ \text { DDE } & p, p^{\prime} \text {-dichlorodiphenyldichloroethylene } \\ \text { DNA } & \text { deoxyribonucleic acid } \\ \text { GLRI } & \text { Great Lakes Restoration Initiative } \\ \text { LOEL } & \text { Lowest Observable Effect Level } \\ \text { PAHs } & \text { polycyclic aromatic hydrocarbons } \\ \text { PCDD/Fs } & \text { dioxins and furans } \\ \text { ppm } & \text { parts per million } \\ \text { PCBs } & \text { polychlorinated biphenyls } \\ \text { TEQs } & \text { toxic equivalents } \\ \mu \mathrm{g} / \mathrm{g} & \text { micrograms per gram } \\ w t . & \text { weight }\end{array}$




\section{Synthesis of Tree Swallow (Tachycineta bicolor) Data for Beneficial Use Impairment (BUI) Assessment at Wisconsin Areas of Concern}

By Christine M. Custer, Thomas W. Custer, and Paul M. Dummer

\section{Introduction}

Assessment of the "Bird or Animal Deformities or Reproductive Problems” Beneficial Use Impairment (BUI) can be accomplished by (1) comparing tissue concentrations to established background and Lowest Observable Effect Level (LOEL) for reproductive effects, or (2) directly measuring reproductive success at Areas of Concern (AOCs) and statistically comparing those rates to minimally impacted reference locations (non-AOCs). Results from recent tree swallow (Tachycineta bicolor) publications (Custer and others, 2016, 2017a, 2017b, 2018, and in press) were used to evaluate this BUI based on both approaches. For both endpoints, a 95-percent confidence interval (CI) was used to test for significant differences. Additional information on BUIs, AOCs, and the program in general can be found in the Great Lakes Water Quality Agreement (2012).

For the first metric, there are good background and reproductive effect threshold LOELs for tree swallow egg concentrations for polychlorinated biphenyls (PCBs), dioxins and furans (PCDD/Fs), and mercury, as well as, for some other organic and inorganic contaminants. For the second assessment, comparisons were made between AOC and non-AOC sites for reproductive success, which was measured as the daily probability of egg failure and the percentage of eggs laid that hatched. Multistate modeling was used to assess whether there was an association between the daily probability of egg failure and a suite of contaminants, including PCBs, but also whether there was an association with ecological variables, such as female age and date within season. Both of these ecological variables are known to affect hatching success in birds. The objective of this report is to synthesize the previously published information to assist in the assessment of the "Bird or Animal Deformities or Reproductive Problems” BUI at 16 sites within the 5 Wisconsin AOCs (table 1). The logic behind this interpretation is applicable to other AOCs as well. 
Table 1. Tree swallow (Tachycineta bicolor) nesting sites investigated within the Wisconsin Areas of Concern, 2010-15.

[AOC, Area of Concern; Wis., Wisconsin; Mich., Michigan; Minn., Minnesota]

\begin{tabular}{lll}
\hline \multicolumn{1}{c}{ AOC } & \multicolumn{1}{c}{ Site } & \multicolumn{1}{c}{ Years } \\
\hline Lower Green Bay And Fox River, Wis. & Ashwaubomay Park & $2012-13$ \\
Lower Green Bay And Fox River, Wis. & BayBeach & $2010-11$ \\
Menominee River, Mich. and Wis. & Menominee River & 2011 \\
Milwaukee Estuary, Wis. & Cedar Creek & $2014-15$ \\
Milwaukee Estuary, Wis. & Kinnickinnic River & $2014-15$ \\
Milwaukee Estuary, Wis. & Lakeshore Park & $2010-11$ \\
Milwaukee Estuary, Wis. & Lincoln Park & $2010-14$ \\
Milwaukee Estuary, Wis. & Three Bridges & $2014-15$ \\
Sheboygan River, Wis. & Black Wolf Run & 2010,2012 \\
Sheboygan River, Wis. & Kohler Landfill & $2013-14$ \\
Sheboygan River, Wis. & Rochester Park & 2013 \\
Sheboygan River, Wis. & Workers Park & $2011-14$ \\
St. Louis River And Bay, Minn. and Wis. & Coffee Ground Flats & $2010-11$ \\
St. Louis River And Bay, Minn. and Wis. & Hog Island & $2010-11$ \\
St. Louis River And Bay, Minn. and Wis. & Miller Creek & $2010-15$ \\
St. Louis River And Bay, Minn. and Wis. & Stryker Bay & $2014-15$ \\
\hline
\end{tabular}

\section{Summary of Published Results}

\section{Methods}

Approximately 20 tree swallow nest boxes were placed at each study site; the boxes that contained eggs were protected from ground predators with metal cylinders. Nest boxes were checked weekly between mid-May and early July during the active nesting season. Generally, each study site was monitored for 2 years, but additional years were sampled at some sites, mainly the more highly contaminated sites, or where remediation was done or imminently planned. Egg samples were collected during early to mid-incubation, and nestling samples were collected when young reached 12 days of age \pm 1 day. Samples were processed in the field according to standard methodologies and then sent to appropriate analytical laboratories at the end of each field season for analysis. For complete details on methods see Custer and others, 2016, 2017a, 2017b, 2018. All animal procedures were reviewed and approved by the USGS Upper Midwest Environmental Sciences Center Institutional Animal Care and Use Committee. 


\section{Exposure to Polychlorinated Biphenyls}

Available in the literature are the LOELs for adverse reproductive effects, as well as background or reference levels for PCBs. Adverse hatching effects begin at 20 parts per million (ppm, which is also expressed as $\mu \mathrm{g} / \mathrm{g}$ ) PCBs wet weight (wt.) in tree swallow eggs (Custer and others, 2003, Neigh and others, 2006). Field reproductive effect thresholds for other wild bird species are similar to effect concentrations found for tree swallows (see review in Harris and Elliott, 2011). Domestic chickens (Gallus domesticus), which are extremely sensitive to PCBs, are an exception to the $20 \mu \mathrm{g} / \mathrm{g}$ wet wt. threshold. For PCBs, geometric mean background concentrations in tree swallow eggs at Great Lakes non-AOCs were $0.32 \mu \mathrm{g} / \mathrm{g}$ wet wt. The mean concentration was $0.34 \mu \mathrm{g} / \mathrm{g}$ wet wt. at multiple reference sites in other studies from across the United States (Results, first paragraph, Custer and others, 2016), which indicates that the nonAOC sites used in this Great Lakes Restoration Initiative (GLRI) work are adequate and appropriate to represent minimally impacted reference locations. The upper range in mean background concentrations at non-AOCs was $0.93 \mu \mathrm{g} / \mathrm{g}$ (Indian Ridge Marsh, Illinois), excluding Little Tail Point, Wisconsin $(1.30 \mu \mathrm{g} / \mathrm{g}$ wet wt.), a non-AOC that may have been influenced by the nearby Lower Green Bay and Fox River AOC (table 1, Custer and others, 2016). The upper mean reference value from reference sites in other studies from across the United States was 1.74 $\mu \mathrm{g} / \mathrm{g}$.

While it is straightforward to interpret concentrations at sites within AOCs that are within the 95 percent CI range of background concentrations for PCBs (7 of 16 sites-Menominee, Three Bridges, Kinnickinnic, Stryker Bay, Coffee Ground Flats, Miller Creek, and Hog Island, table 1, Custer and others, 2016) or that have mean values of $\geq 20 \mu \mathrm{g} / \mathrm{g}$ wet wt., the LOEL for reproductive effects (none of Wisconsin AOCs are in this category), other information can be used in combination to help understand whether, or how "significant," exposures to PCBs are at the remaining 9 sites. Except for Black Wolf Run (mean $=4.55 \mu \mathrm{g} / \mathrm{g}$ wet wt., maximum value of $13.4 \mu \mathrm{g} / \mathrm{g}$ ) and Ashwaubomay Park (mean = $3.27 \mu \mathrm{g} / \mathrm{g}$ wet wt., maximum value of $6.19 \mu \mathrm{g} / \mathrm{g}$ ), concentrations at the remaining sites were 10-15 times lower than the $20 \mu \mathrm{g} / \mathrm{g}$ wet wt. threshold where reproductive impairment begins to be evident. To put the $20 \mu \mathrm{g} / \mathrm{g}$ wet wt. LOEL for tree swallows in perspective, even on the Housatonic River, Massachusetts, which had mean egg PCB concentrations of between $31.5 \mu \mathrm{g} / \mathrm{g}$ wet wt. and $101 \mu \mathrm{g} / \mathrm{g}$ wet wt., there was only slight reproductive impairment, and this impairment was mainly associated with the PCDD/F contamination of the PCBs used in that area (Custer and others, 2003). Even with the extraordinary level of PCB exposure on the Housatonic River, the percent hatching exceeded 80 percent at all sites, even those that were located on the most contaminated main stem of that river. That hatching rate is similar to the non-AOC hatching rate in the GLRI studies (77 percent, table 5, Custer and others, 2018). So while mean PCB contamination at Ashwaubomay Park and Black Wolf Run is elevated, it is not cause for concern for reproductive impairment in tree swallows based on tissue concentrations. Sediments in the Fox River near Ashwaubomay Park were dredged in 2014, and concentrations in tree swallow tissues since then have dropped significantly (Custer and others, in press).

\section{Exposure to Other Contaminants}

All five Wisconsin AOCs were below background exposure for PCDD/F toxic equivalents (TEQs, fig. 4, Custer and others, 2016). The TEQ system calculates a single value for the sample that captures the toxicity of the mixture. The TEQ system incorporates the fact of 
variable toxicity of different individual congeners such that a less toxic congener is given less weight than a more toxic congener in the calculations. Not all PCDD/F congeners, nor PCB congeners, are included in TEQ calculations. Total PCDD/Fs are merely the sum of the concentration of all congeners, irrespective of toxicity, while PCDD/F TEQs are the sum of the products of the toxic equivalence factor times the concentration for each congener that has a toxic equivalence factor (Van den Berg and others, 1998). Total PCDD/Fs indicated a slightly different picture than PCDD/F TEQs at one AOC, the Lower Green Bay Fox River AOC (fig. 3, Custer and others, 2016). In this case, total PCDD/Fs were above background concentrations and approached the LOEL for reproductive effects whereas that was not the case for PCDD/F TEQs. The PCDD/F TEQs were well below background concentrations in the Lower Green Bay Fox River AOC. This occurred because octachlorodibenzo-p-dioxin dominated at this AOC (48 percent of the PCDD/Fs; p/ 3074, second column, Custer and others, 2016). This congener, however, has relatively low toxicity (Van den Burg and others, 1998), which accounted for the slightly differing results between total PCDD/Fs and PCDD/F TEQs.

Trace elements, including mercury, were at background concentrations at all Wisconsin AOCs (T. Custer, unpub. data, 2018). The pesticide p,p' -dichlorodiphenyldichloroethylene (DDE) as well as other legacy pesticides were also at background concentrations (fig. 6 and tables 5 and 6, Custer and others, 2016). These background concentrations were far below any effect thresholds.

\section{Reproductive Success as a Beneficial Use Impairment Assessment Endpoint- Polychlorinated Biphenyls}

Results from quantifying reproductive success for at least 2 years at each site were consistent with the relatively low exposure to PCBs. Based on these low levels of exposure for PCBs, no reproductive effects due to PCBs would be predicted. The daily probability of egg failure differed from the average rate at non-AOCs at only 3 of 16 sites within Wisconsin AOCs (fig. 5, Custer and others, 2018). Those sites were Lakeshore Park, Bay Beach, and Workers Park. Exposure to PCBs likely did not contribute much, if anything, to those results, because neither PCBs nor PCB TEQs were associated with the daily probability of egg failure (table 3, Custer and others, 2018). Additionally, there were ecological factors that explained the higher egg mortality rates at some sites regardless of contaminant exposure. Those factors included depredation rates (table 6, Custer and others, 2018) and age of female (table 1, Custer and others, 2018). Depredation rates were held constant in the modeling work because depredation events did not occur at all locations. Depredation, however, was important at some sites. Workers Park had 9 percent of nests depredated compared to an overall depredation rate of 4 percent at nonAOCs. Depredation contributed substantially to the lower egg survival rate at Workers Park (table 6, Custer and others, 2018). A contributing factor to the reduced egg survival at Bay Beach was age of female. Age was included in the top four models explaining egg mortality rates (table 1, Custer and others, 2018). First year females (browner plumage) had a lower percentage of nests that hatched all or some eggs and a lower percentage of all eggs laid that hatched (table 7, Custer and others, 2018). The percentage of females that were brown at Bay Beach was 50 percent (Suppl. table 3, Custer and others, 2018), and compared to 29 percent overall.

By using percent of eggs laid that hatched (table 6, Custer and others, 2018) as an alternate reproductive success metric, only two sites in Wisconsin, Black Wolf Run and Workers Park, differed from non-AOCs. Again, this reduced success was most likely due to depredation, 
which accounted for 18 percent (Black Wolf Run) and 9 percent (Workers Park) of hatching failures at those two sites (table 6, Custer and others, 2018).

\section{Reproductive Success and Other Contaminants}

While PCDD/F TEQs, but not total PCDD/Fs, were negatively associated with reproductive success, expressed as the daily egg failure rates (table 3, Custer and others, 2018) across all GLRI study sites, this class of contaminants was not an issue at Wisconsin AOCs. Mean PCDD/F TEQs at all Wisconsin AOCs were below background concentrations (fig. 4, Custer and others, 2018). Even the maximum PCDD/F TEQ exposure in eggs at any of the Wisconsin sites was below background concentrations (table 3, Custer and others, 2016), so $\mathrm{PCDD} / \mathrm{Fs}$ are not cause for concern for reproductive impairment at Wisconsin AOC sites.

In contrast, there was a weak association between total polycyclic aromatic hydrocarbons (PAHs) in nestling diet samples and the daily egg failure rate (fig. 3, Custer and others, 2018). Lakeshore Park had the highest PAH exposure of any GLRI study site (table 1, Custer and others, 2017a); Three Bridges, to a lesser extent, had elevated exposure to PAHs as well. Additional sampling for PAHs, as well as monitoring reproductive success, is continuing in the Milwaukee Estuary AOC. None of the other legacy contaminants tested were associated with the daily probability of egg failure (table 3, Custer and others, 2018), nor were two emerging contaminants, polybrominated diphenyl ethers or the perfluorinated compounds (Custer and others, 2016, 2018).

\section{Biomarkers and Beneficial Use Impairment Assessment}

To assist in interpreting both the exposure and reproductive success data, especially for sites that were in "grey areas," that are defined as slightly above background concentrations for tissue exposure or just outside the 95-percent CIs for reproductive success, bioindicator responses can be a useful tool. If biomarker responses are within the 95-percent CIs ranges for the non-AOCs, then the contaminant exposure that is occurring is not eliciting a significant physiological response in individual birds. If there are no physiological responses out of the normal range for the biomarkers measured, then this provides further weight of evidence that the contaminants, although present, are not at levels of concern.

A series of biomarkers were assessed in nestling tree swallows, and comparisons made between sites at AOCs and non-AOCs. These bioindicators included ethoxyresorufin- $O-$ dealkylase, five measures of oxidative stress, and deoxyribonucleic acid (DNA) damage (Custer and others, 2017b). DNA damage was measured in red blood cells, so it is a measurement of short-term perturbations in somatic, rather than germ cells. Neither ethoxyresorufin- $O$-dealkylase (fig. 2 in Custer and others, 2017b), total sulfhydryl (fig. 5 in Custer and others, 2017b), nor protein bound sulfhydryl activities (fig. 6 in Custer and others, 2017b) were out of the normal range for any of the 16 sites within Wisconsin AOCs. The other three oxidative stress measures were all within normal boundaries at all sites including the Wisconsin AOCs. Although DNA damage was outside the 95-percent CI for non-AOCs at Kohler Landfill, Kinnickinnic River, Lincoln Park, and Cedar Creek, none of these four sites differed from the most DNA-damaged non-AOC site (Indian Ridge Marsh, fig. 4 in Custer and others, 2017b). There were no clear associations with DNA damage and any of the contaminants measured. Cause for these somatic cell perturbations is currently unknown. 


\section{Other Species}

Tree swallows are a mid-trophic level consumer classified as such because they eat primarily the aerial stage of benthic aquatic insects. This typically results in lower exposure in eggs to some contaminants such as PCBs and DDE, but the swallows are actually exposed to, and accumulate, higher concentrations of PCDD/Fs compared to piscivorous waterbirds such as herons, cormorants, and gulls; swallows also have higher exposure than piscivorous birds when contamination is expressed as PCDD/F TEQs and PCB TEQs (table 2, Custer and others, 2014). Other piscivorous species (Custer and others, 2010), that nest in the same location as tree swallows also show this same food chain inversion for PCDD/F TEQs and PCB TEQs.

Tree swallow data can be used to infer exposure to and effects at other trophic levels when these other species of interest have not been sampled either because of their rarity, their inaccessibility, or other reasons. In Green Bay, Wisconsin, double-crested cormorants (Phalacrocorax auritus), black-crowned night herons (Nycticorax nycticorax), and herring gulls (Larus argentatus), which nested in close proximity to the tree swallows at the Bay Beach site, were sampled. As expected, the cormorant (3.45 $\mu \mathrm{g} / \mathrm{g}$ wet wt.) and herring gull $(6.78 \mu \mathrm{g} / \mathrm{g}$ wet wt.) eggs had 1.8 and 3.4 times higher exposure to total PCBs in their eggs than did the tree swallows (table 2, Custer and others, 2014). Exposure in the night herons was similar to tree swallows. These relationships can be used to infer exposure to other bird species at other sites if desired. Even the herring gull exposure, which was the highest of the three piscivorous waterbird species, was $\sim 3$ times lower than the LOEL where reproductive impairment has been demonstrated in birds. Exposure of these 3 piscivorous species to PCDD/Fs, when expressed as TEQs, was 3-7 times less than exposure in tree swallows (table 2, Custer and others, 2014) and hence should also not be cause for concern.

It should be noted that by 2010, exposure to PCBs and DDE in four species nesting in lower Green Bay had declined substantially since the early to mid-1990s (fig. 2, Custer and others, 2014). Also, DDE rather than PCBs was implicated in reproductive impairment of cormorants in Green Bay in the mid-1990s (Custer and others, 1999). By 2010, the levels of DDE in cormorant eggs (1.61 $\mu \mathrm{g} / \mathrm{g}$ wet wt., table 2, Custer and others, 2014) had fallen below the level (2.8 $\mu \mathrm{g} / \mathrm{g}$ wet wt.) where all eggs were successfully hatching (table 6, Custer and others, 1999) in that earlier study.

\section{Conclusions}

All lines of evidence, based on tree swallow results, point to a lack of effects from polychlorinated biphenyls (PCBs) at Wisconsin Areas of Concern (AOCs). Tissue concentrations of PCBs in eggs at 44 percent of Wisconsin AOC sites were less than exposure at the most contaminated non-AOC location (0.93 parts per million wet weight) excluding Little Tail Point. Even those sites with slightly elevated PCBs in eggs had neither ethoxyresorufin-O-dealkylase induction nor elevated total sulfhydryl activity that would indicate sufficient exposure to contaminants to elicit even a physiological response in the biomarkers measured. Finally, tissue concentrations of PCBs in eggs were generally 10-15 times lower than the lower threshold (20 parts per million wet weight), for the Lowest Observable Effect Level where effects on hatching begin. The daily probability of egg failure was elevated at only three sites, and at these sites, PAHs were most likely responsible at one site (Lakeshore Park), depredation at one site (Workers Park), and a higher proportion of first year and unknown age females at the third (Bay 
Beach). Using percent hatching, only two sites were below the average percentage at non-AOCs, and both were most likely because of elevated predation rates. Sites within Wisconsin AOCs were at background exposure levels for dioxin and furan toxic equivalents, mercury, and other legacy contaminants, and none of these other contaminants are expected to be causing impaired reproduction.

\section{References Cited}

Custer, C.M., Custer, T.W., Dummer, P.M., and Munney, K.L., 2003, Exposure and effects of chemical contaminants on tree swallows nesting along the Housatonic River, Berkshire County, Massachusetts, USA, 1998-2000: Environmental Toxicology and Chemistry, v. 22, p. $1605-1621$.

Custer, C.M., Custer, T.W., and Dummer, P.M., 2010, Patterns of organic contaminants in eggs of an insectivorous, an omnivorous, and a piscivorous bird nesting on the Hudson River, New York, USA: Environmental Toxicology and Chemistry, v. 29, no. 10, p. 2286-2296, accessed February 5, 2018, at https://doi.org/10.1002/etc.276.

Custer, C.M., Custer, T.W., Dummer, P.M., Goldberg, D., and Franson, J.C., 2016, Concentrations and spatial patterns of organic contaminants in tree swallow (Tachycineta bicolor) eggs at United States and Binational Great Lakes Areas of Concern, 2010-2015: Environmental Toxicology and Chemistry, v. 35, no. 12, p. 3071-3092, accessed February 5, 2018, at https://doi.org/10.1002/etc.3496.

Custer, C.M., Custer, T.W., Etterson, M.A., Dummer, P.M., Goldberg, D., and Franson, J.C., 2018, Reproductive success and contaminant associations in tree swallows (Tachycineta bicolor) nesting in U.S. and Binational Great Lakes’ Areas of Concern, Ecotoxicology, accessed March 12, 2018, at https://doi.org/10.1007/s10646-018-1913-9.

Custer, C.M., Custer, T.W., Dummer, P.M., Goldberg, D., and Franson, J.C. (in press) Annual variation in polychlorinated biphenyl (PCB) exposure in tree swallow (Tachycineta bicolor) eggs and nestlings at Great Lakes Restoration Initiative (GLRI) study sites: Environmental Monitoring and Assessment.

Custer, T.W., Custer, C.M., Hines, R.K., Gutreuter, S., Stromborg, K.L., Allen, P.D., and Melancon, M.J., 1999, Organochlorine contaminants and reproductive success of doublecrested cormorants from Green Bay, Wisconsin, USA: Environmental Toxicology and Chemistry, v. 18, p. 1209-1217.

Custer, T.W., Dummer, P.M., Custer, C.M., Franson, J.C., and Jones, M., 2014, Contaminant exposure of birds nesting in Green Bay, Wisconsin, USA: Environmental Toxicology and Chemistry, v. 33, no. 8, p. 1832-1839, accessed February 5, 2018, at https://doi.org/10.1002/etc.2609.

Custer, T.W., Custer, C.M., Dummer, P.M., Goldberg, D., Franson, J.C., and Erickson, R.A., 2017a, Organic contamination in tree swallow (Tachycineta bicolor) nestlings at United States and binational Great Lakes Areas of Concern: Environmental Toxicology and Chemistry, v. 36, no. 3, p. 735-748, accessed February 5, 2018, at https://doi.org/10.1002/etc.3598.

Custer, T.W., Custer, C.M., Dummer, P.M., Bigorgne, E., Oziolor, E.M., Karouna-Renier, N., Schultz, S., Erickson, R.A., Aagaard, K., and Matson, C.W., 2017b, EROD activity, chromosomal damage, and oxidative stress in response to contaminants exposure in tree swallow (Tachycineta bicolor) nestlings from Great Lakes Areas of Concern: Ecotoxicology (London, England), v. 26, no. 10, p. 1392-1407, accessed February 5, 2018, at https://doi.org/10.1007/s10646-017-1863-7. 
Great Lakes Water Quality Agreement, 2012, Available from:

(https://www.epa.gov/greatlakes/glwqa/) or https://binational.net/annexes/a1./

Harris, M.L., and Elliott, J.E., 2011, Effects of polychlorinated biphenyls, dibenzo-p-dioxins and dibenzofurans, and polybrominated diphenyl ethers in wild birds, in Beyer, W.N., and Meador, J.P., eds., Environmental contaminants in biota-Interpreting tissue concentrations (2nd ed.): Boca Raton, Fla., CRC Press, p. 477-528, accessed February 5, 2018, at https://doi.org/10.1201/b10598-16.

Neigh, A.M., Zwiernik, M.J., Bradley, P.W., Kay, D.P., Park, C.S., Jones, P.D., Newsted, J.L., Blankenship, A.L., and Giesy, J.P., 2006, Tree swallow (Tachycineta bicolor) exposure to polychlorinated biphenyls at the Kalamazoo River superfund site, Michigan, USA: Environmental Toxicology and Chemistry, v. 25, no. 2, p. 428-437, accessed February 5, 2018, at https://doi.org/10.1897/04-493R.1.

Van den Berg, M., Birnbaum, L., Bosveld, A.T.C., Brunstrom, B., Cook, P., Feeley, M., Giesy, J.P., Hanberg, A., Hasegawa, R., Kennedy, S.W., Kubiak, T., Larsen, J.C., Rolaf van Leeuwen, F.X., Djien Liem, A.K., Nolt, C., Peterson, R.E., Poellinger, L., Safe, S., Schrenk, D., Tilllitt, D., Tysklind, M., Younes, M., Waern, F., and Zacharewski, T., 1998, Toxic equivalency factors (TEFs) for PCBs, PCDDs, PCDFs for humans and wildlife: Environmental Health Perspectives, v. 106, no. 12, p. 775-792, accessed February 5, 2018, at https://doi.org/10.1289/ehp.98106775. 